\title{
Performance Estimation of Grid Connected Photovoltaic Systems in Different Regions in Paraná
}

\author{
Camila de Oliveira Silveira ${ }^{*}$ \\ https://orcid.org/0000-0002-6391-5211 \\ Jair Urbanetz Junior ${ }^{1}$ \\ https://orcid.org/0000-0001-9355-1730
}

\begin{abstract}
${ }^{1}$ Federal Technological University of Parana (UTFPR), Post Graduate Program in Energy Systems (PPGSE), Solar Energy Laboratory (LABENS), Curitiba, Parana, Brazil.

Editor-in-Chief: Alexandre Rasi Aoki

Associate Editor: Alexandre Rasi Aoki
\end{abstract}

Received: 2020.02.18; Accepted: 2021.04.14.

*Correspondence: camila.osilveira@hotmail.com; Tel: +55-41-999726294 (C.O.S.).

\section{HIGHLIGHTS}

- The generation of photovoltaic solar energy is proportional to the solar radiation in the location where the system is installed.

- Figures of merit may fluctuate depending on the season.

- The performance of a photovoltaic system varies according to the photovoltaic cell technology employed.

\begin{abstract}
The obtaining of electric energy from solar energy through photovoltaic systems shows great growth due to the solar potential present in the Brazilian territory. In the State of Paraná, studies are recurrent in public and private sectors on the development and performance of this technology. The installation and commissioning processes of photovoltaic plants are linked to the expectation of energy generation and the performance of the system through the figures of merit. The feasibility of the project can be confirmed when the results of these parameters are satisfactory and correspond to averages obtained from already consolidated surveys. The six photovoltaic systems implemented at the Federal Technological University of Paraná have expectations of generation and performance consistent with those of previous studies and will contribute to scientific advancement on the behavior of systems with different technologies located in different regions in the state.
\end{abstract}

Keywords: photovoltaic systems; generation of photovoltaic energy; photovoltaic cells; figures of merit.

\section{INTRODUCTION}

Due to the great use of the solar potential for electricity generation and the growing expansion of the photovoltaic industry in the world market, the dimensioning of Grid Connected Photovoltaic Systems (GCPVS) depends on the knowledge of the characteristics of the photovoltaic cells, enabling the commissioning and the detection of errors in order to increase system reliability [1]. 
The energy conversion efficiency indexes of a photovoltaic cell have great relevance in performance analysis of an GCPVS. However, the losses that occur during this conversion process, especially those caused by temperature, significantly impact the results obtained. The modules of crystalline silicon are subject to lower performance when exposed to an ambient temperature above $25{ }^{\circ} \mathrm{C}$, however, thin film technologies are less susceptible to this situation [2].

In this context, the power generation of an GCPVS is closely related to the conditions of installation of the system, installed capacity and technology by which the photovoltaic modules are composed. Until 2020, the installed capacity of distributed generation by solar energy was approximately $627 \mathrm{GWp}$ in the world [3] and $276 \mathrm{MWp}$ in Parana [4], respectively. In partnership with Paranaense Company of Energy (COPEL), the Solar Energy Laboratory (LABENS) of the Federal Technological University of Paraná (UTFPR) was tasked with designing and analyzing the performance of photovoltaic systems deployed in six UTFPR campuses, allowing to determine their respective functionalities and compare the behavior of installed technologies in Parana state. In this first analysis, an estimate of the photovoltaic potential will be made through figures of merit.

\section{MATERIAL AND METHODS}

Each photovoltaic system consists of four photovoltaic cell technologies, namely: monocrystalline silicon (m-Si); polycrystalline silicon ( $\mathrm{p}-\mathrm{Si}$ ); copper, indium, and gallium diselenide (CIGS); and cadmium telluride (CdTe). The installed powers of each technology are defined in Table 1, resulting in a total of $13.1 \mathrm{kWp}$ of power for the system.

Table 1. Installed power of each technology.

\begin{tabular}{ccc}
\hline & Technology & Installed power \\
\hline \multirow{2}{*}{ Crystalline silicon } & $\mathrm{m}-\mathrm{Si}$ & $5,11 \mathrm{kWp}$ \\
& $\mathrm{p}-\mathrm{Si}$ & $4,69 \mathrm{kWp}$ \\
\multirow{2}{*}{ Thin films } & CIGS & $1,68 \mathrm{kWp}$ \\
& CdTe & $1,53 \mathrm{kWp}$ \\
\hline
\end{tabular}

The GCPVS are installed following the optimal conditions described in [5], with the photovoltaic modules oriented to geographical north and the inclination angle corresponding to the latitude of the location, whose values are shown in Table 2.

Table 2. Latitude of cities where GCPVS are installed.

\begin{tabular}{ll}
\hline City & Latitude \\
\hline Campo Mourão & $24,06^{\circ} \mathrm{S}$ \\
Cornélio Procópio & $23,19^{\circ} \mathrm{S}$ \\
Curitiba & $25,44^{\circ} \mathrm{S}$ \\
Medianeira & $25,30^{\circ} \mathrm{S}$ \\
Pato Branco & $26,20^{\circ} \mathrm{S}$ \\
Ponta Grossa & $25,05^{\circ} \mathrm{S}$ \\
\hline
\end{tabular}

In this first analysis, an expectation of GCPVS performance was performed using studies developed by [6] of another system that has been in operation since February 29, 2016 at UTFPR Campus Curitiba Neoville, illustrated in Figure 1.

With a total installed power of $10.2 \mathrm{kWp}$, the system consists of 2 sets of 17 photovoltaic modules model ELCO-A300P, connected in series, resulting in 34 modules of polycrystalline silicon, with $300 \mathrm{Wp}$ each one. The inverter is three-phase without transformer (Chint Power, model CPS SCA 10KTL-DO), at $380 \mathrm{~V}$ of high efficiency, with nominal power of $10 \mathrm{~kW}$. Installed on the roof of the building and occupying an area of approximately $68 \mathrm{~m}^{2}$, this was the second GCPVS implemented at UTFPR Campus Curitiba. The panels were installed with optimum conditions, oriented to the geographical north with azimuth deviation of $0^{\circ}$ and with an inclination equal to $25^{\circ}$, whose value represents the latitude of the city of Curitiba [7]. 


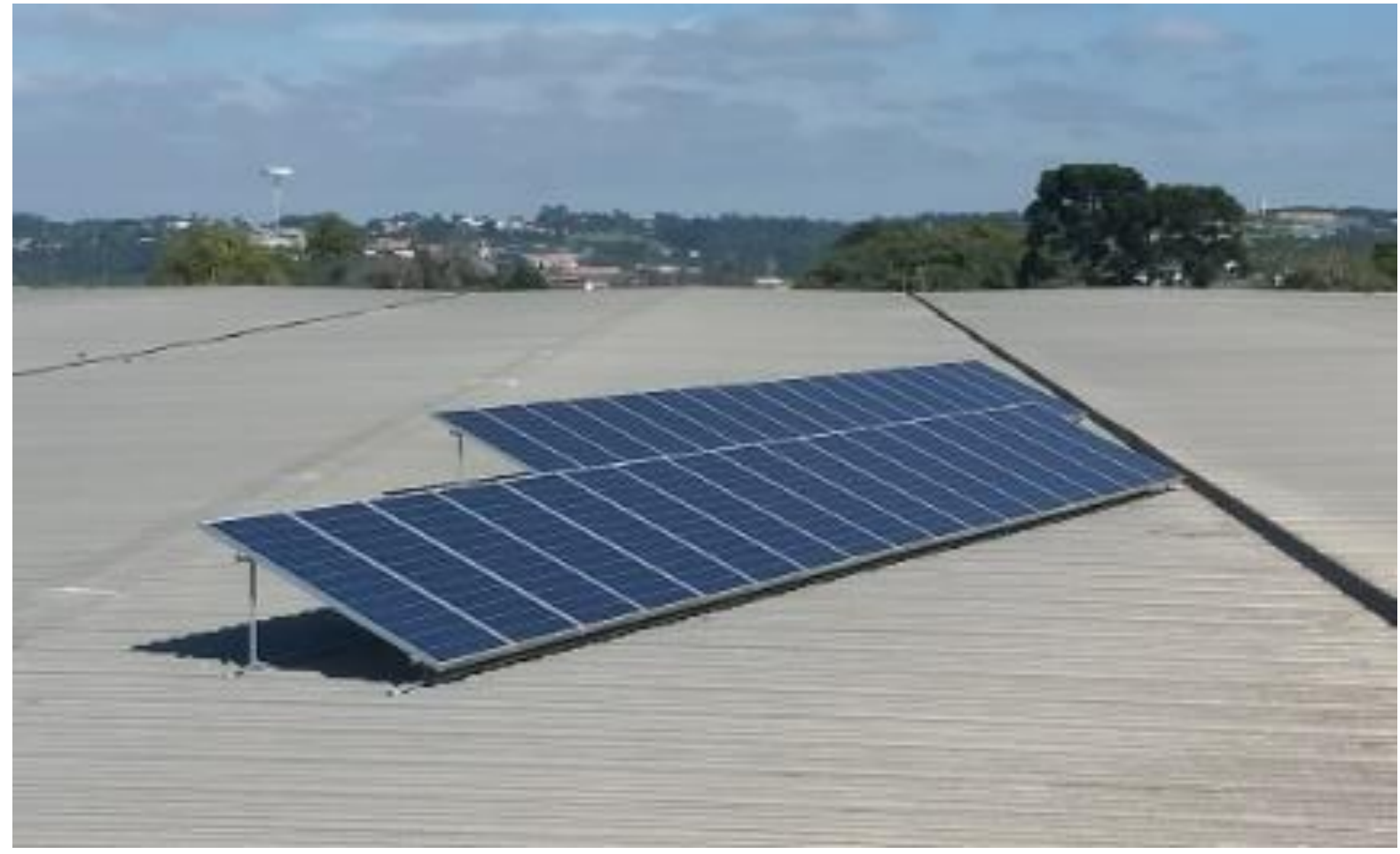

Figure 1. Neoville's GCPVS.

To analyze the performance of the GCPVS, it is necessary to acquire the irradiation data available on site. In this analysis, the Atlas of Solar Energy of the State of Paraná [2] was used through the interactive map available on its web platform, which contains historical irradiation data of the cities where the GCPVS are installed. The irradiation values in the inclined plane of latitude that were considered for the campuses of Campo Mourão, Cornélio Procópio, Curitiba, Medianeira, Pato Branco and Ponta Grossa are shown in Chart 1.

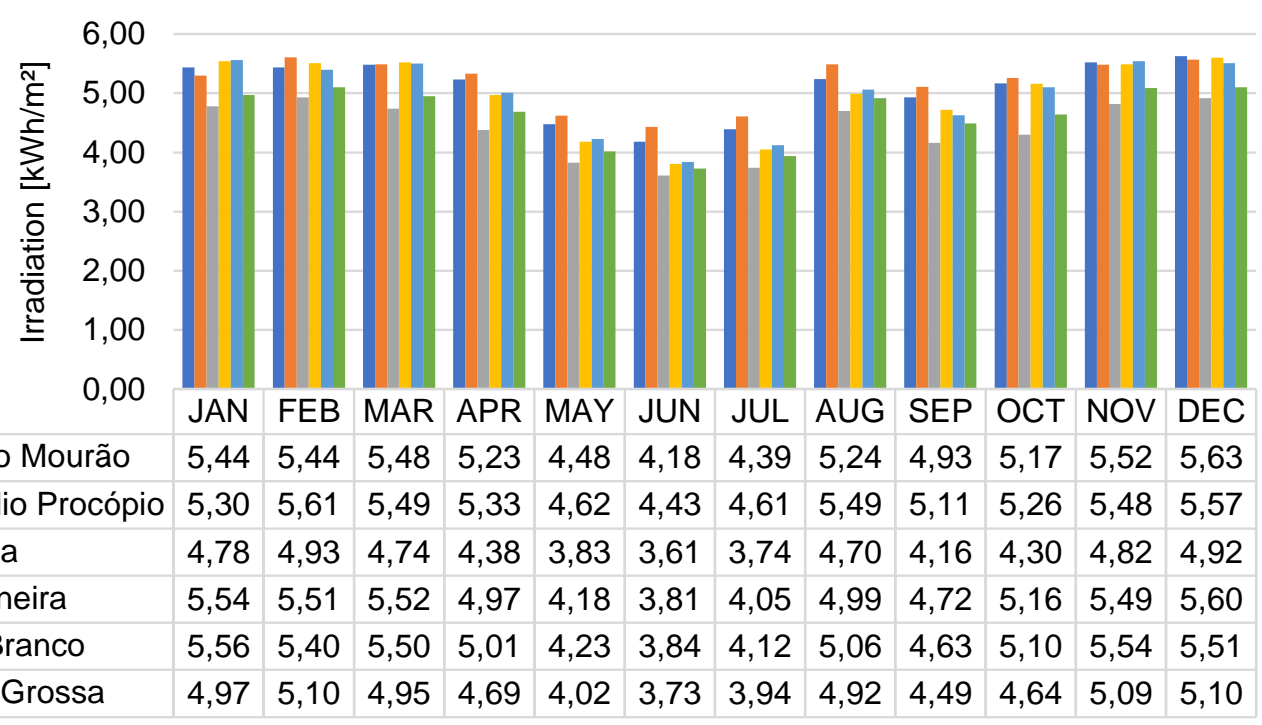

Chart 1. Average monthly irradiation on the inclined plane of latitude.

Concomitant with the acquisition of irradiation data, it is necessary to collect the energy generation data from the GCPVS to perform the performance analysis. In this study, energy generation was estimated using Equation 1.

$$
E=\frac{P_{F V} \cdot H_{\text {tot }} \cdot P R}{G}
$$


Where:

$E=$ energy generated $[k W h] ;$

$\mathrm{P}_{\mathrm{FV}}=$ installed power of GCPVS [kWp];

$\mathrm{H}_{\text {tot }}=$ total irradiation in one day $\left[\mathrm{kWh} / \mathrm{m}^{2}\right]$;

$\mathrm{G}=$ solar irradiance of $1 \mathrm{~kW} / \mathrm{m}^{2}$.

According to Silveira and coauthors [6], the performance ratio of GCPVS in operation at Neoville is $78.48 \%$, whose value was adopted as a reference for the analysis of the estimated energy generation in this article. The Charts $2-5$ show the monthly forecast of energy generated according to the irradiation of each location for the technologies of $\mathrm{m}-\mathrm{Si}, \mathrm{p}-\mathrm{Si}, \mathrm{CIGS}$ and $\mathrm{CdTe}$, in this order.

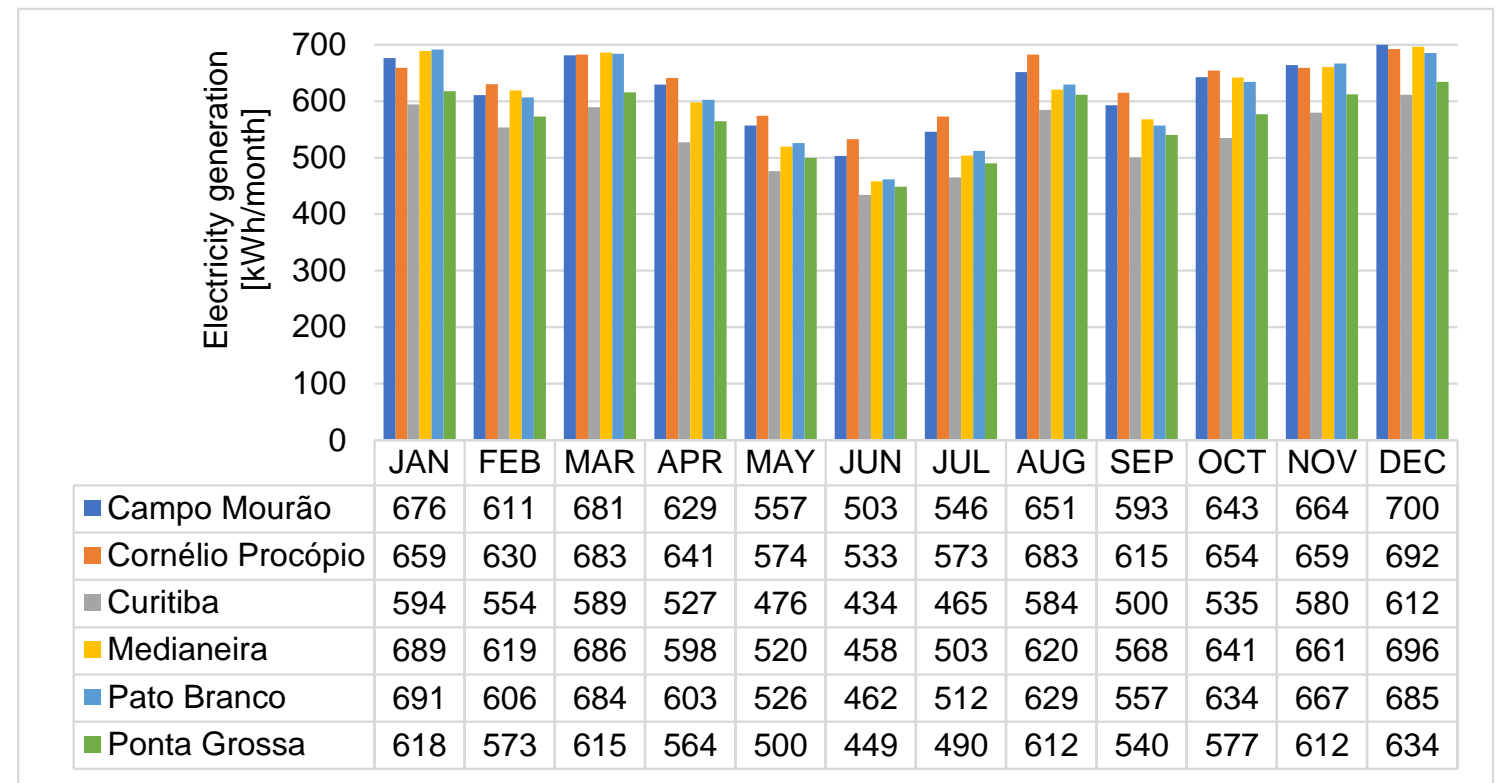

Chart 2. Estimated electricity generation for $\mathrm{m}$-Si technology.

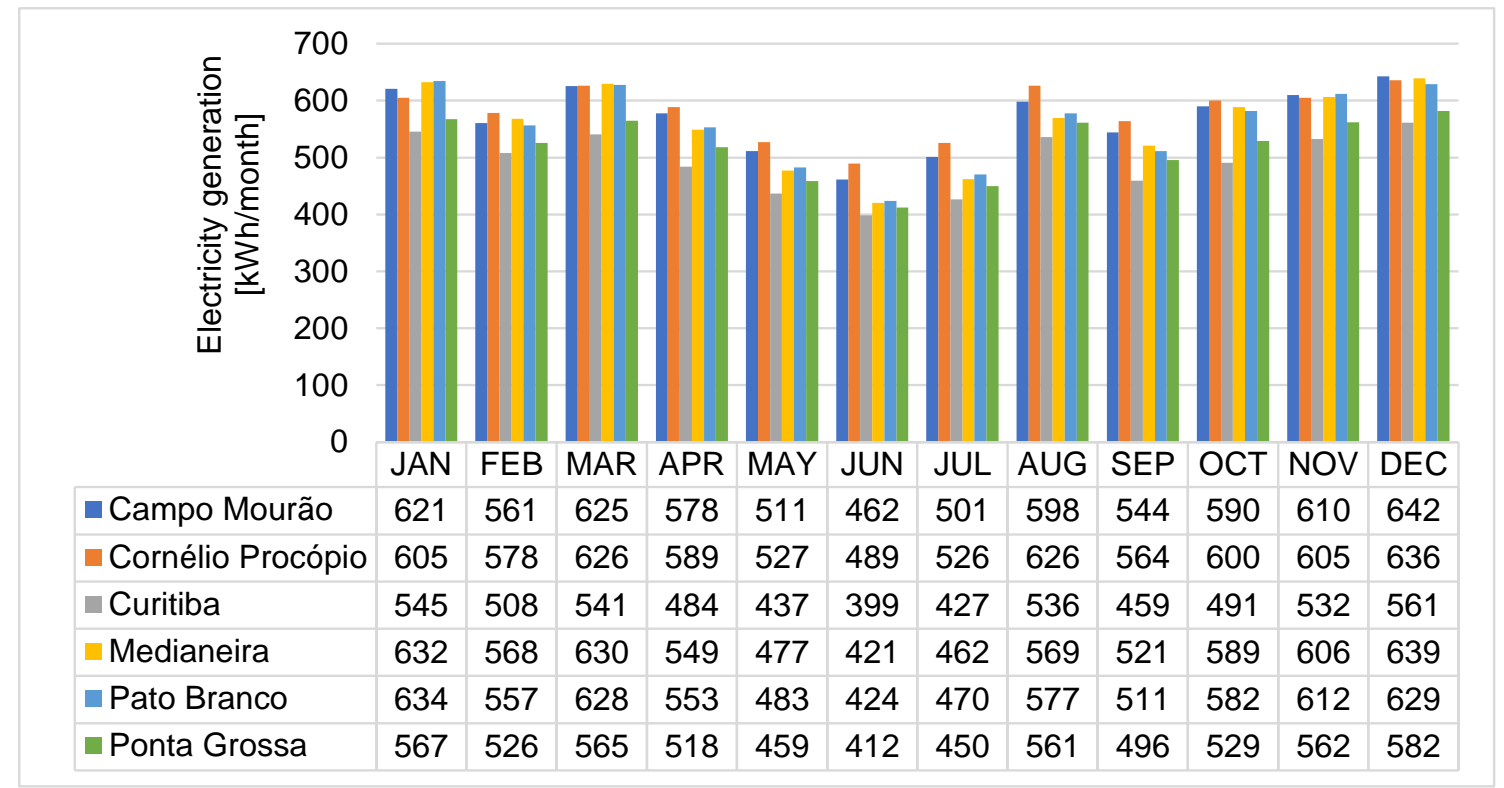

Chart 3. Estimated electricity generation for $p$-Si technology. 


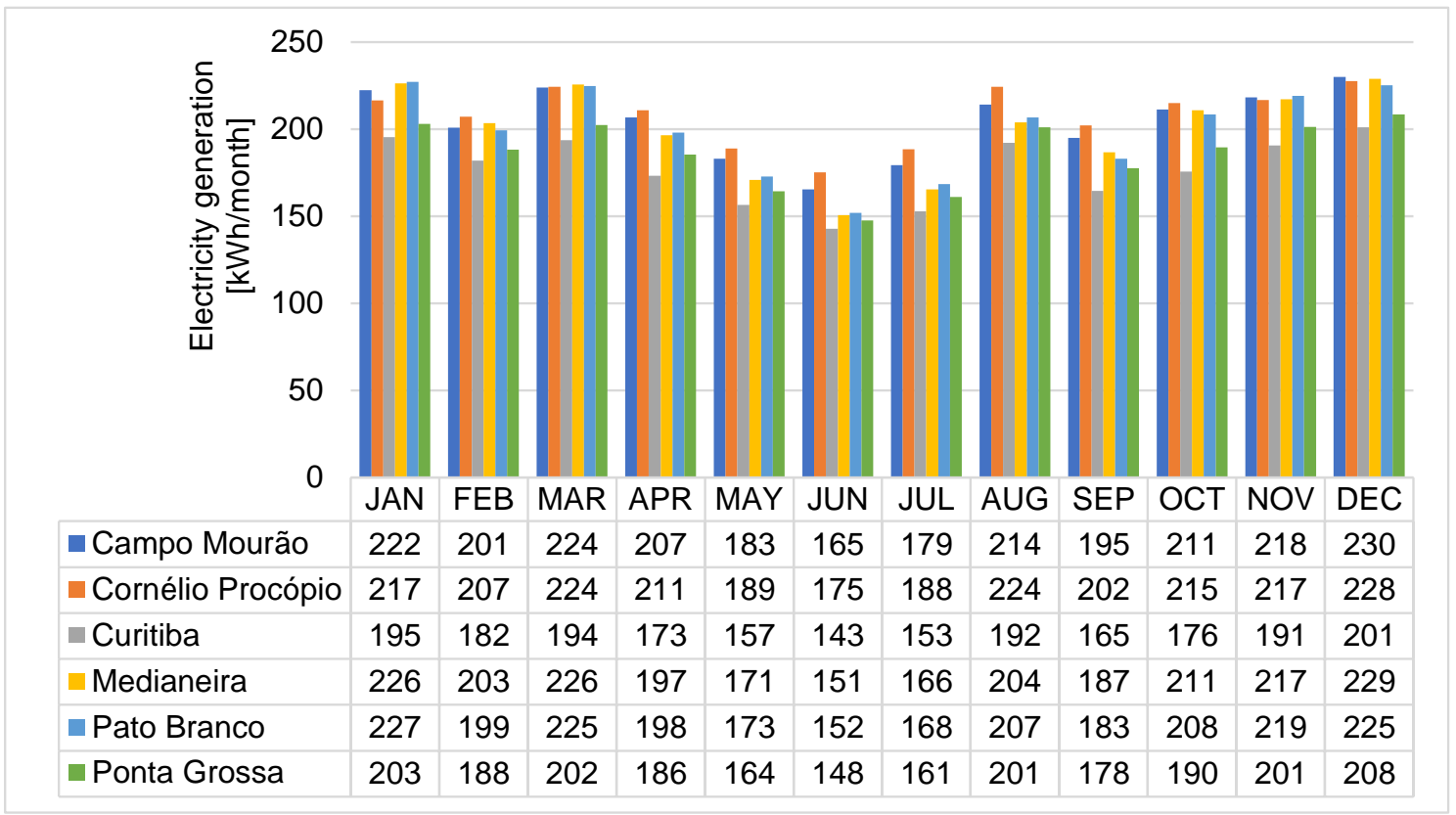

Chart 4. Estimated electricity generation for CIGS technology.

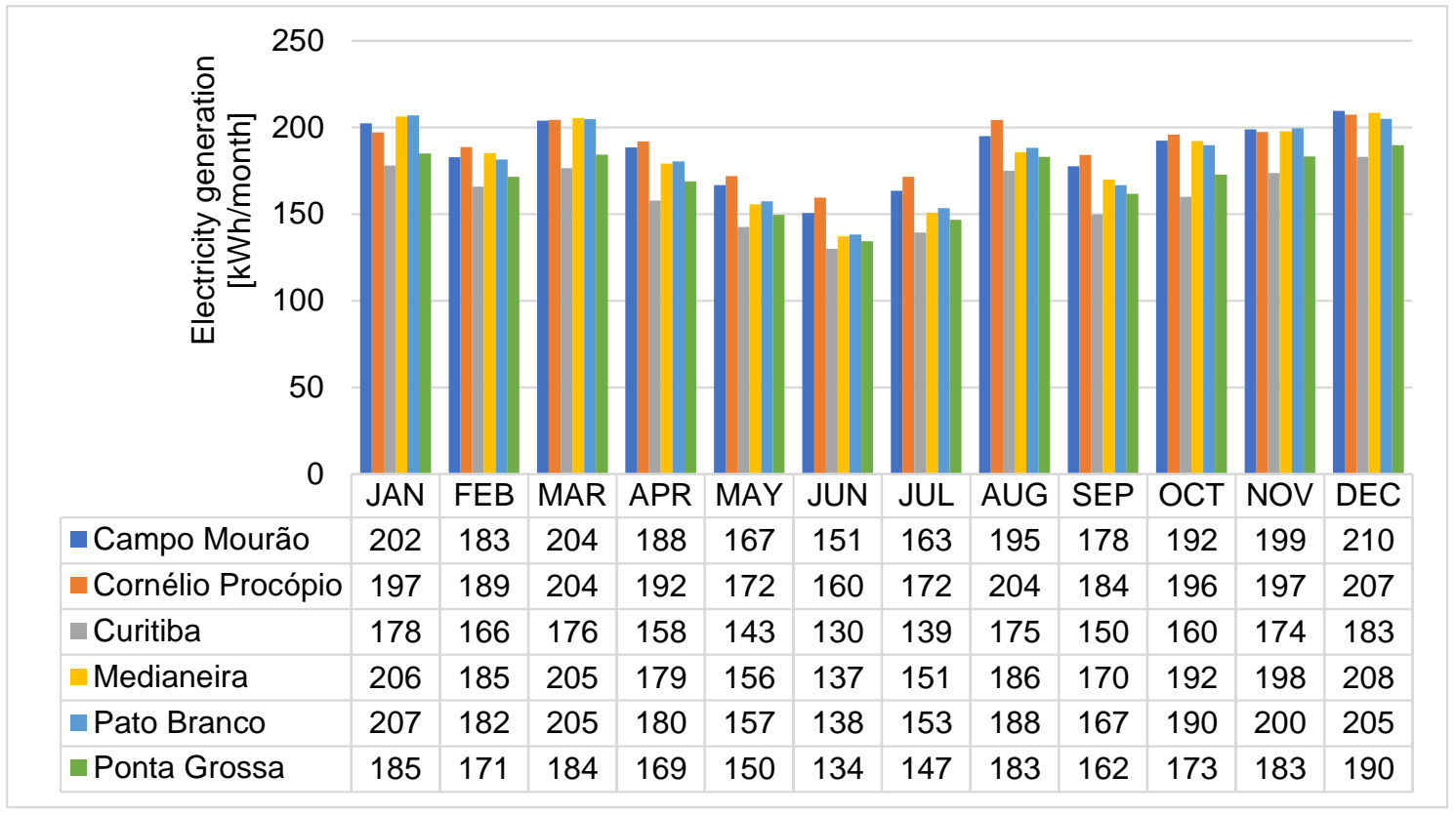

Chart 5. Estimated electricity generation for CdTe technology.

From the adopted considerations and the calculations to estimate the monthly values of electric power generation of each technology in the six campuses, it is possible to obtain from the figures of merit the expected performance of GCPVS in the university.

The figures of merit considered in this analysis are classified in: Capacity Factor, Final Yield and Performance Ratio and can be calculated according to Equations 2-4, respectively.

$$
\text { Capacity Factor }=\frac{\text { energy generated }}{\text { nominal power }{ }^{*} \text { period }}
$$




$$
\begin{gathered}
\text { Final Yield }=\frac{\text { energy generated }}{\text { installed power }} \\
\text { Performance Ratio }=\frac{\text { final yield }}{\text { irradiation } / 1000}
\end{gathered}
$$

The capacity factor allows to evaluate the amount of energy that the system could generate if it operated at its nominal power for 24 hours. Final Yield, on the other hand, reveals in a normalized way, the real production of electrical energy of the system. Finally, the performance ratio determines the percentage of conversion of solar energy into electrical energy, already considering the losses that occurred in this process [8].

\section{RESULTS}

With the irradiation data established and the estimated energy generation calculated, it was possible to estimate the figures of merit to analyze the performance of the GCPVS that are installed in the six campuses of university. It is worth mentioning that the performance ratio was not estimated, since it involves several losses due to shading, dirt, inverter, temperature, among other factors that were not measured and will not be evaluated in this analysis of the work. The performance ratio of $78.48 \%$ attributed in the methodology served as a basis for estimating the capacity factors and final yields of the GCPVS in question.

The estimates of the monthly analysis and the annual average of the GCPVS capacity factors are represented in Chart 6 and Table 3, respectively.

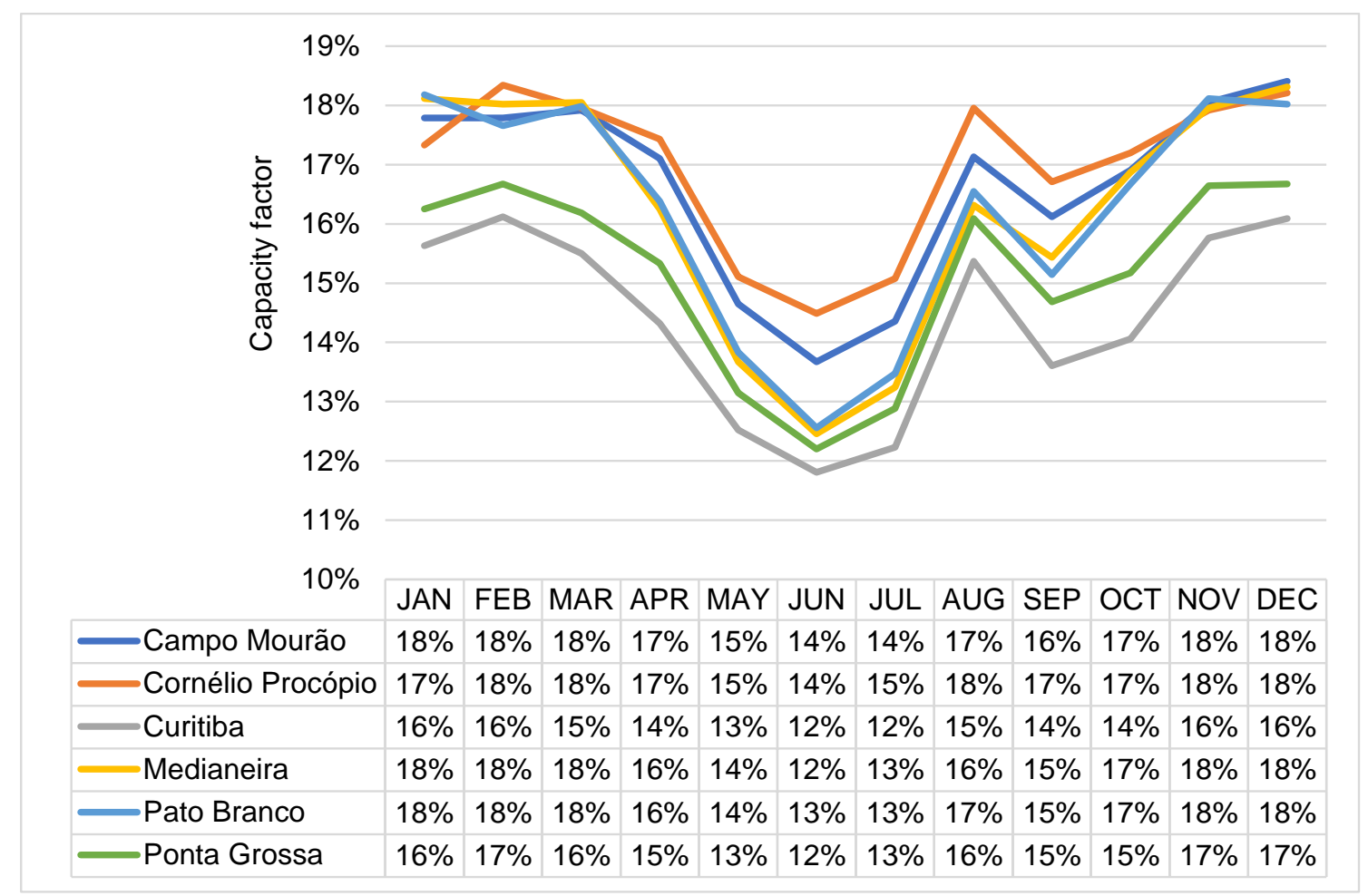

Chart 6. Estimated monthly average of capacity factors.

Table 3. Estimated annual average capacity factors.

\begin{tabular}{cccccc}
\hline Campo Mourão & Cornélio Procópio & Curitiba & Medianeira & Pato Branco & Ponta Grossa \\
\hline $17 \%$ & $17 \%$ & $14 \%$ & $16 \%$ & $16 \%$ & $15 \%$ \\
\hline
\end{tabular}


Estimates of the monthly analysis and the annual total of GCPVS final yields are shown in Chart 7 and Table 4, respectively.

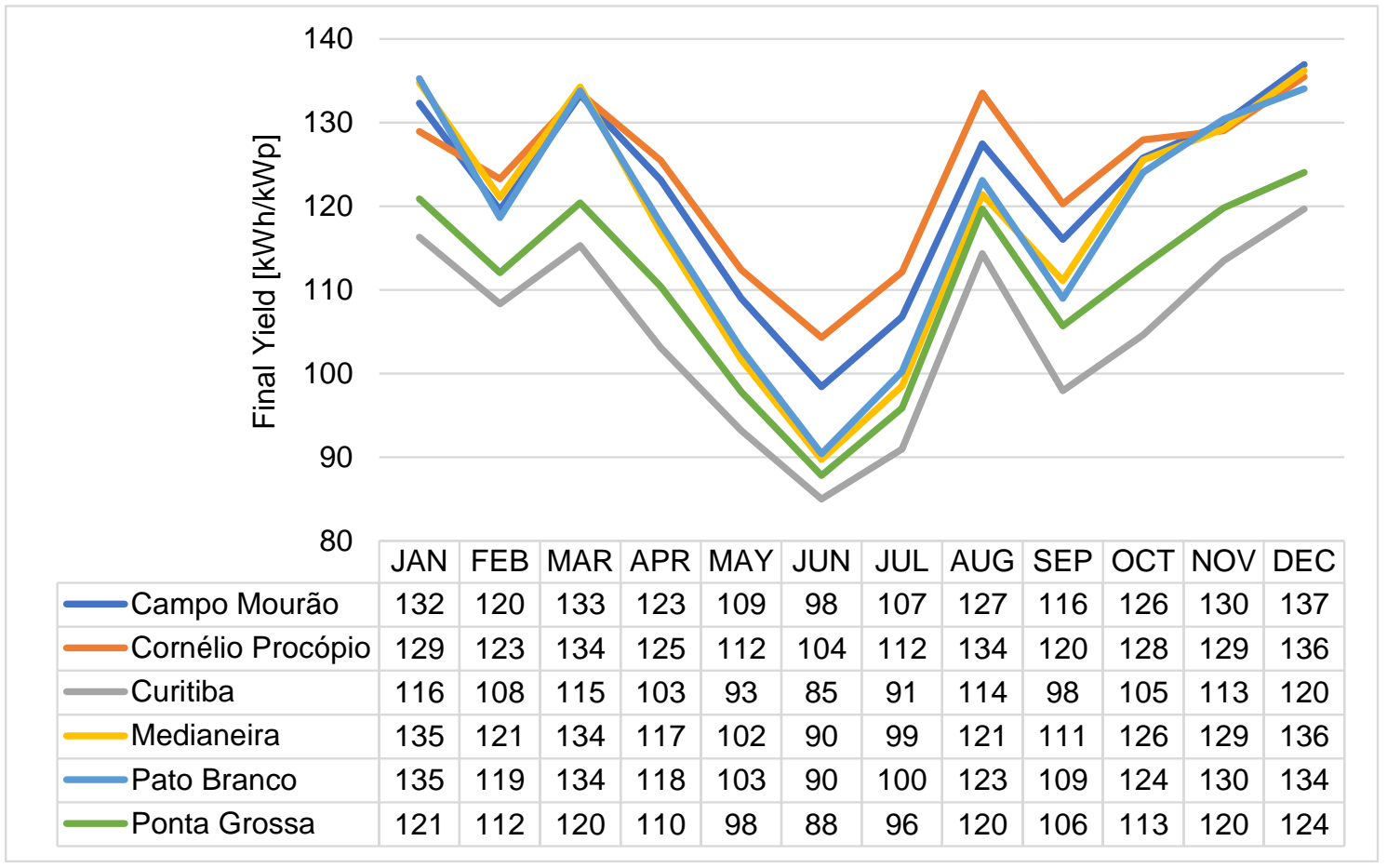

Chart 7. Estimated monthly average of final yields.

Table 4. Estimated annual final yield (kWh/kWp).

\begin{tabular}{cccccc}
\hline Campo Mourão & Cornélio Procópio & Curitiba & Medianeira & Pato Branco & Ponta Grossa \\
\hline \multirow{2}{*}{1,459} & 1,487 & 1,262 & 1,421 & 1,420 & 1,328 \\
\hline
\end{tabular}

This performance analysis did not consider the figures of merit indexes of each technology, that is, the GCPVS was evaluated. When assigning a fixed value for the performance ratio, the temperature coefficients in relation to the nominal power of the different cell technologies presented in Table 5 [9-12] were neglected.

Table 5. Temperature coefficient in relation to the nominal power of the photovoltaic cell.

\begin{tabular}{cccc}
\hline $\mathbf{m}-\mathbf{S i}$ & $\mathbf{p}-\mathrm{Si}$ & $\mathbf{C I G S}$ & $\mathbf{C d T e}$ \\
\hline$-0.39 \% /{ }^{\circ} \mathrm{C}$ & $-0.40 \% /{ }^{\circ} \mathrm{C}$ & $-0.32 \% /{ }^{\circ} \mathrm{C}$ & $-0.25 \% /{ }^{\circ} \mathrm{C}$ \\
\hline
\end{tabular}

It is also worth mentioning that the losses associated with the percentage of $78.48 \%$ should not be the same for the other systems. For a deeper analysis, it would be necessary to estimate the performance ratio of each GCPVS studied.

\section{DISCUSSION}

In a monthly analysis, the capacity factor shows an estimated variation of $12 \%$ to $18 \%$, in addition to the predominance of higher levels in summer months due to the higher level of solar radiation at this time of the year. In an annual analysis, the lowest average calculated corresponds to the city of Curitiba, which presented a capacity factor such of studies by [6], equivalent to $13.92 \%$. This fact shows that the forecast of capacity factors for other cities can be considered adequate.

The final yield forecast estimated values slightly higher than those presented by [2]. In addition, there is a difference of approximately $38 \mathrm{kWh} / \mathrm{kWp}$ between the expected final yiel and the calculated one by [6] in Curitiba. In a monthly analysis, the reduction of this index happens as the winter months approach, mainly in 
June, due to the lower irradiation rates in the place. The peaks presented in August for both the capacity factor and final yield point out that the parameters of irradiation and power generation are linked, as both showed an increase at this time.

Unlike capacity factors and final yields, performances ratios should be higher in winter months, when the solar incidence is lower. This fact must also be related to the decrease in the ambient temperature and in the photovoltaic cells at this time, with lower losses of efficiency due to temperature.

In relation to the performance of each technology, the installed powers of $\mathrm{m}$-Si and $\mathrm{p}$-Si are about three times greater when compared to other technologies and, consequently, the energy production estimate showed superior results mainly in January, the month of greatest solar incidence. Losses due to temperature in $\mathrm{m}$-Si cells are high in this type of technology $\left(-0.39 \% /{ }^{\circ} \mathrm{C}\right.$, as shown in Table 5$)$. On the other hand, thin film cells, more specifically CdTe cells, show the lowest losses when compared to other technologies $\left(-0.25 \% /{ }^{\circ} \mathrm{C}\right.$, as shown in Table 5). This scenario shows that although CdTe has the lowest forecast of power generation due to the lower installed power, this technology may present superior performance results, followed by CIGS, m-Si and p-Si technology.

In general, the greatest potential for the installation of GCPVS is found in Campo Mourão, Cornélio Procópio, Pato Branco and Medianeira, since the performance rates in these locations tend to be higher when compared to the others. Thus, it was possible to geographically identify the regions in which solar energy is most prominent in Parana's territory.

\section{CONCLUSION}

The collection of irradiation data from the Solar Energy Atlas of Paraná made it possible to calculate the GCPVS expected energy generation, as well as their respective performances. The viability of the GCPVS performance estimate under study in this work was evidenced, since the predicted indexes are close to the real values of another system that operates with similar characteristics.

Considering that the exact performance will be calculated with real measured data, it will be possible to compare the estimated results with those obtained, in addition to establishing the figures of merit for each technology present in the photovoltaic system in different regions of Paraná, since all parameters will be measured in real time.

Funding: This research was funded by COPEL - Distribution, by the means of the Research \& Development project "ANEEL PD 2866-0464/2017 - Methodology for Analysis, Monitoring and Management of Distributed Generation by Encouraged Sources".

Acknowledgments: The authors would like to thank UTFPR for the support and infrastructure available for the development of this research and COPEL - Distribution for the support and funding of the resources to carry out this Research \& Development project "ANEEL PD 2866-0464/2017 - Methodology for analysis, monitoring and management of distributed generation by encouraged sources".

Conflicts of Interest: "The funders had no role in the design of the study; in the collection, analyses, or interpretation of data; in the writing of the manuscript, or in the decision to publish the results".

\section{REFERENCES}

1. Zilles R, Macêdo WN, Galhardo MAB, Oliveira SHF. Sistemas Fotovoltaicos Conectados à Rede Elétrica. 1st ed. São Paulo: Oficina de Textos; 2012. 208 p.

2. Tiepolo GM, Pereira EB, Urbanetz Junior J, Pereira SV, Gonçalves AR, Lima FJL, Costa RS, Alves AR. Atlas de energia solar do Estado do Paraná. 1st ed. São José dos Campos: Instituto Nacional de Pesquisas Espaciais; 2017. $80 \mathrm{p}$.

3. REN21. Renewables 2020 Global Status Report [Internet]. 2020. [cited 2021, Feb 15] Paris: REN21 Secretariat, 2020. Available from: https://y3i6c3u4.rocketcdn.me/wp-content/uploads/2019/05/gsr_2020_full_report_en.pdf.

4. ANEEL. Unidades Consumidoras com Geração distribuída [Internet]. 2020. [cited 2021, Feb 15]. Available from: http://www.aneel.gov.br/outorgas/geracao/-/asset_publisher/mJhnKli7qcJG/content/registro-de-central-geradorade-capacidade-reduzida/655808.

5. Pinho JT, Galdino MA. Manual de engenharia para sistemas fotovoltaicos. 1st ed. Rio de Janeiro: CEPEL/CRESESB; 2014. $530 \mathrm{p}$.

6. Silveira CO, Tonolo EA, Krasnhak LB, Urbanetz Junior J. Acompanhamento de desempenho e contribuição da capacidade instalada de SFVCR frente ao panorama nacional. XXII Congresso Brasileiro de Automática; 2018; João Pessoa: SBA; 2018. 8 p. 
7. Urbanetz Junior J, Tiepolo GM, Casagrande Junior EF, Tonin FS, Mariano JD. Geração distribuída fotovoltaica: o caso dos sistemas fotovoltaicos da UTFPR em Curitiba. X Congresso Brasileiro de Planejamento Energético; 2016; Gramado: SBPE; 2016. 13 p.

8. Benedito RS. Caracterização da geração distribuída de eletricidade por meio de sistemas fotovoltaicos conectados à rede, no Brasil, sob os aspectos técnico, econômico e regulatório [dissertation]. São Paulo: Universidade de São Paulo; 2009. 109 p.

9. Hanwha Q CELLS. Módulo Solar Q.Antum [Internet]. 2018. [cited 2019, Sep 14]. Available from: https://www.qcells.com/dam/jcr:bc0a8e73-6ef6-4e27-8992-a51364025156/Hanwha_Q_CELLS_Data_sheet_QPEAK_LG5.0.G_355-370_2018-06_Rev02_AU.pdf/.

10. Hanwha Q CELLS. Módulo Solar Q.Antum [Internet]. 2018. [cited 2019, Sep 14]. Available from: https://www.qcells.com/dam/jcr:f391e618-7f78-4d84-a071-d59b76897025/Hanwha_Q_CELLS_Data_sheet_QPOWER_LG5_315-335_Global_2017-08_Rev02_EN.pdf/.

11. Solibro GMBH. CdTe thin film solar module CX3 [Internet]. 2013. [cited 2019, Sep 14].Available from: https://solibrosolar.com/fileadmin/image/05_News_Downloads/Downloads/Data_sheets/G2.3/Solibro_Datenblatt_SL2-F_G23_2017-12_Rev01_EN.pdf/.

12. Calyxo GMBH. CdTe thin film solar module CX3 [Internet]. 2013. [cited 2019, Sep 14]. Available from: http://www.go-pure.eu/download/datenblatt_CX3_eng_85.pdf/.

CC (7) (5) 2021 by the authors. Submitted for possible open access publication under the terms and (c) (1) 8 conditions of the Creative Commons Attribution (CC BY NC) license EY NC (https://creativecommons.org/licenses/by-nc/4.0/). 